\title{
Long term oxygen therapy and factors affecting patient adherence
}

\author{
Uzun süreli oksijen tedavisi ve hasta uyumunu etkileyen faktörler
Serhat Erol*, Şehnaz Olgun Tandoğdu, Şule Taş Gülen, Burcu Oktay, Pınar Tunç, Kadriye Terzioğlu

Pulmonary Medicine Clinic (S. Erol, MD, Ş. T. Gülen, MD, B. Oktay, MD, P. Tunç, MD, K. Terzioğlu), Mardin State Hospital, TR-47200 Mardin, Department of Pulmonary Medicine (Ş. O. Tandoğdu, MD), Kızıltepe State Hospital, TR-47400

\begin{abstract}
Aim. Long-term oxygen therapy delays the adverse effects of chronic hypoxemia and improves survival. Long term oxygen therapy must be administered at least fifteen hours a day in order to be effective. Adherence to long-term oxygen therapy is the main problem. In this study we evaluated patient adherence to long-term oxygen therapy and reasons of poor compliance. Method. A questionnaire was administered to 51 patients whom long-term oxygen therapywas prescribed at Mardin State Hospital or Kizlltepe State hospital between 2009 and March 2012. Questionnaire was administered face to face or on telephone call. Results. Among 51 patients 32 were male, 19 were female. Thirty seven patients $(72.5 \%)$ had chronic obstructive pulmonary disease. Thirteen patients $(25.5 \%)$ were using oxygen at least fifteen hours a day. Remaining 38 patients $(74.5 \%)$ were using less than fifteen hours. Of these 38 patients 22 patients were using oxygen whenever they had dyspnea, 3 patients at night and remaining 13 patients were using oxygen between 2 to 10 hours. Forty four patients reported improvement with long-term oxygen therapy , 2 patients said that they didn't notice any improvements and 5 patients were not sure about benefits of long-term oxygen therapy. Twenty seven patients $(52.9 \%)$ knew that they should use at least fifteen hours. Among these 27 patients 15 patients were using less than prescribed hours, although they knew they should use at least fifteen hours. Only 4 patients reported reasons for poor compliance. One patient was afraid of getting addicted, one patient suffered from noise and two patients reported that they were not at home during day time. Conclusion. This study revealed that compliance with long-term oxygen therapy is an important issue. We think that poor compliance is due to inadequate patient information. Home care service can help for both patient education and followup.
\end{abstract}

Keywords: Chronic respiratory failure, long-term oxygen therapy, patient adherence

Özet

Amaç. Uzun süreli oksijen tedavisi kronik hipoksinin yan etkilerini geciktiren ve sağkalımı artıran bir tedavidir. Etkin olabilmesi için oksijenin günde en az on beş saat kullanılması gerekmektedir. $\mathrm{Bu}$ calışmada hastalarımızın tedaviye uyum sorununu ve uyumsuzluğun sebeplerini araştırdık. Metod. 2009 ve Mart 2012 arasında Mardin ve Kizıltepe Devlet Hastanelerinde uzun süreli oksijen tedavisi reçete edilen 51 hastaya telefonla veya yüz yüze anket uygulandi. Bulgular. Elli bir hastadan 32'si erkek 19'u kadındı. Otuz yedi hastanın $(\% 72,5)$ tanısı kronik obstruktif akciğer hastalığı idi. On üç $(\% 25,5)$ hasta günde en az 15 saat oksijen kullanıyordu. Kalan otuz sekiz $(\% 74,5)$ hasta ise reçetelenen 15 saatten daha az kullanıyordu. Bu 38 hastadan 22'si nefes darlığ hissettiklerinde, 3 'ü gece ve kalan 13 hasta ise 2 ile 10 saat arasında düzensiz kullanıyordu. Kırk dört hasta uzun süreli oksijen tedavisinden fayda gördüğünü ifade etti. İki hasta fayda görmediğini kalan 5 hasta ise fayda görüp görmediğinden emin olmadığını ifade etti. Yirmi yedi hasta oksijeni en az günde onbeş saat alması gerektiğini bildiğini söyledi. Yirmi yedi hastadan 15'i almas gerektiği süreyi bildiği halde daha az kullanıyordu. Sadece 4 hasta oksijeni az kullanmaları için sebep bildirdiler. Bir tanesi bağımlılıktan korktuğunu, bir tanesi gürültüden rahatsız olduğunu kalan iki tanesi ise gündüzleri evde olmadıkları için az kullandıklarını ifade ettiler. Sonuç. Bu çalışma ile uzun süreli oksijen tedavisine uyumun önemli bir sorun olduğu gösterildi. Hasta uyumsuzluğunun sebebinin, hastaların bilgilendirilmelerindeki eksiklik olduğunu düşünüyoruz. Evde bakım tedavi ünitelerinin hastaların bilgilendirilmelerinde ve takiplerinde yardımcı olabilir.

Anahtar sözcükler: Kronik solunum yetmezliği, uzun süreli oksijen tedavisi, hasta uyumu 
Geliş tarihi/Received: June 13, 2012; Kabul tarihi/Accepted: August 01, 2012

\section{*Corresponding author:}

Dr. Serhat Erol, Göğüs Hastalıkları Kliniği, Mardin Devlet Hastanesi, TR-47200 Mardin. E-mail: drserol@yahoo.com

\section{Introduction}

Hypoxemia and respiratory failure are the most important causes of morbidity and mortality due to chronic respiratory diseases. Hypoxemia results in pulmonary vasocontruction, pulmonary hypertension and cor pulmonale. Long-term oxygen therapy (LTOT) is the only therapeutic modality to stop or slow down the progression of adverse effects of chronic hypoxemia. Also LTOT improves survival and decreases dyspnea [1, 2]. The Global Initiative for Chronic Obstructive Lung Disease (GOLD) guidelines recommend LTOT for patients with $\mathrm{PaO} 2$ at or below $55 \mathrm{mmHg}$, or for patients $\mathrm{PaO} 2$ between $55 \mathrm{mmHg}$ and $59 \mathrm{mmHg}$ if there is evidence of pulmonary hypertension, peripheral edema suggesting cardiac failure, or polycythemia (hematocrit above \%55) [3]. Concentrator is the most prescribed system for oxygen delivery. To be effective oxygen must be administred at least 15 hours a day $[3,4]$. Today, patient adherence to LTOT is a major problem. Many studies showed that patients are prone to use oxygen less than 15 hours. There are many reasons for poor compliance, such as side effects (nasal dryness, headache), fear of addiction, limited daily activities and noise [5].

In this study we aimed to find out whether patients comply to the prescribed duration of LTOT. And also we aimed to figure out the problems with compliance to LTOT.

\section{Material and method}

A questionnaire was administered to patients face to face or with telephone call. Telephone questionnaire was administered to patients who were too ill to come to hospital. We interviewed with patients directly or with their care giving relatives. Concentrators were prescribed at Mardin and Kiziltepe State hospitals between 2009 and March 2012. Statistical analyses were performed with SPSS 16 software.

\section{Results}

Fifty one patients completed the questionnaire. Patients characteristics are summarized in Table-1. Thirty two patients were male and 19 were female. Chronic obstructive pulmonary disease (COPD) was the most frequent disease in both genders. The youngest patient was 28 years old and the oldest was 90 years old. Mean age was $70 \pm 12$.

Table 1. Patient characteristics.

\begin{tabular}{llll}
\hline \multirow{2}{*}{ Gender } & & $\mathbf{n}$ & $\mathbf{\%}$ \\
& Male & 32 & 62.7 \\
Disease & Female & 19 & 37.3 \\
& COPD & 37 & 72.5 \\
& ILD & 3 & 5.9 \\
& Kyphoscoliosis & 1 & 2.0. \\
& OSAS & 1 & 2.0 \\
& Bronchiectasis & 2 & 3.9 \\
& Tb Sequelae & 3 & 5.9 \\
& Asthma & 4 & 7.8 \\
\hline Smoking & Never & 22 & 43.1 \\
& Quit & 15 & 29.4 \\
& Current Smoker & 14 & 27.5 \\
\hline
\end{tabular}

COPD: Chronic obstructive pulmonary disease, ILD: Interstitial lung diases, OSAS: Obstructive sleep apnea syndrome, Tb: Tuberculosis 
Three patients had BIPAP(Bilevel positive air pressure) (1 for OSAS and 2 were for type II respiratory failure). Sixteen patients were using oxygen less than one year, 13 patients were using for one year, 13 patients were using for two years, 9 patients were using for three years (Figure-1). Forty four $(86.3 \%)$ patients said they noticed improvement, 2 (3.9\%) patients said they didn't notice improvements, 5 (9.8\%) mentioned that they are not sure if they had any improvements with LTOT. Table- 2 summarises distribution of patients due to improvement to diseases.

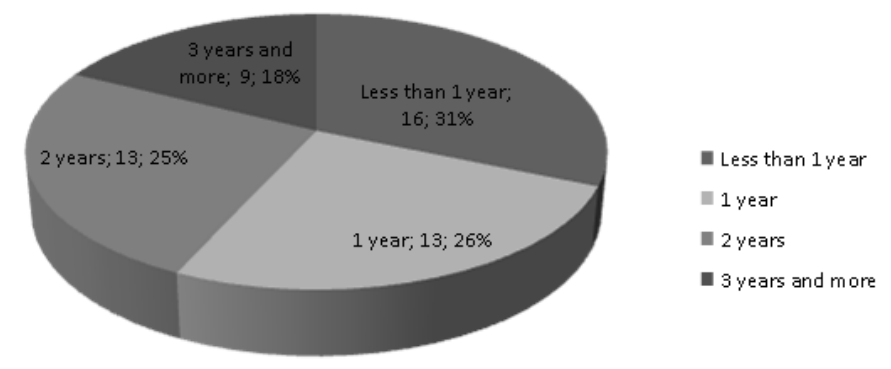

Figure 1. LTOT Prescription period (n; \%).

Table 2. Patient improvement with LTOT.

\begin{tabular}{llll}
\hline \multicolumn{5}{l}{ Did you notice any } & improvement & with LTOT? \\
\hline Disease & Yes & No & Not sure \\
COPD & 32 & 2 & 3 \\
ILD & 3 & 0 & 0 \\
Kyphoscoliosis & 1 & 0 & 0 \\
OSAS & 0 & 0 & 1 \\
Bronchiectasis & 2 & 0 & 0 \\
Tb Sequelae & 2 & 0 & 1 \\
Asthma & 4 & 0 & 0 \\
\hline
\end{tabular}

Thirteen patients $(25.5 \%)$ were using oxygen at least 15 hours a day, 38 patients $(74.5 \%)$ were using oxygen less than prescribed hours. Of these 38 patients significant number of patients [22] reported to use oxygen for breathlessness, 3 were using at night and remaining 13 patients were using irregularly between 2 to 10 hours. Among these 38 patients 4 reported reasons for poor compliance. One was afraid of getting addicted to oxygen, one patient suffered from noise and two said that they were not at home during daytime. Most of the patients tolerated LTOT well. Only 4 patients complained of nasal dryness or headache (Table-3).

Table 3. Patient compliance and side effects.

\begin{tabular}{llll}
\hline & & n & \% \\
\hline Hours of oxygen administration & 15 hours and more & 13 & 25,5 \\
& When dyspneic & 22 & 43,1 \\
& At night & 3 & 5,9 \\
& Irregular (2 to 10 hours) & 13 & 25,5 \\
\hline Reasons for nonadharence & Noise & 1 & \\
& Fear of addiction & 1 & \\
& Not at home day time & 2 \\
\hline Complaint about oxygen & Headache & 2 & \\
& Nasal dryness & 2 \\
\hline
\end{tabular}

We asked patients if they knew they should use oxygen at least fifteen hours a day. Twenty four (47.1\%) patients answered that they didn't know and 27 (52.9\%) patients knew that they should use at least fifteen hours a day. Interestingly 15 patients were using less than fifteen hours a day although they knew that they should use at least fifteen 
hours. Twenty seven (52.9\%) patients didn't know the prescribed flow rate. They were using concentrator at the flow rate that was set by firm representative when first prescribed. Only one patient had saturation check while using oxygen at home. Only one patient received maintenance for concentrator by the firm. None of the patients had home care unit service. Except one, all patients had relatives taking care of them.

\section{Discussion}

In this study we aimed to evaluate patients' compliance with LTOT and figure out the reasons for poor compliance. Compliance is the major issue for LTOT. Studies revealed that patient compliance changed between 40-65\%. Previous Turkish studies showed that in Turkey proper use of LTOT is between $29-31 \%$ [6-8]. Our patients' compliance was $25.5 \%$. This is much less than previous Turkish studies. National health care system fully covers the expenses of LTOT. Average cost of concentrator is 1000 Turkish Liras. When other expenditures are added (nebulisator, medication etc) chronic respiratory failure has a huge economic burden. If not administrated properly LTOT has no benefits $[9,10]$. It is only waste of money. So for patient's own health and for economical reasons compliance is vital. We think the main reason for poor compliance is patients' missunderstanding of LTOT. Some patients thought oxygen as an medication to reduce dyspnea. As a result, most of the patients were using oxygen when they feel breathless. Possibly this misunderstanding is a result of patients' inadequate information. Also most of the patients didn't know the prescribed flow rate. Flow rate is set by the firm representative at the beginning of therapy and if flow rate is changed -for example accidentally- possibly, they won't recognize it or can't set the true flow rate. Our study revealed that our patients got instructions about concentrator from firm respresentative not from doctors or nurses. They don't get home care service. More important is none of the patients had saturation check while using LTOT at home. So we don't know if LTOT is administered at proper flow rate. Although patient education and socio-economical status is very important for compliance, these results can't be explained only with patient characteristics. All these data show that, we can't inform our patients properly. Of course we are talking to patients, trying to give informations. But it seems that this is not enough. We have to remind and make cautions about their situation more strongly and explain the importance of compliance very often. Doctors have to see large number of patients every day. Also they have to take care of hospitalized patients. Because of this heavy workload, doctors have only a few minutes for each patient. So patients leave our office with millions of questions in their mind. May be written information, underlining some points about their situation and instructions about concentrator can help patients. Follow-up is crucial for these patients. Home care units can do routine home visits. These units can remind important points about disease and concentrator to patients and caregivers, do saturation check, medications prescriptions and -if needed- organize hospital admission. As reported before home care program reduces the mortality and hospital admissions [11]. According to the 2010 estimations the median age of Turkey is 28.9. In 2050, the median age of Turkey is predicted to be 40.2. This data shows that Turkey has an aging population [12]. As a result; in the near future respiratory problems are going to be more prominent. We'll have to care about more patiens with chronic respiratory problems. There will be more patients who need hospital admission and/or ICU. So we have to find new methods for management of patients with chronic respiratory diseases. Home care units can also be the answer for this incoming problem. Our patients were lucky. Except one, all patients had relatives taking care of them. Although they have relatives helping them, patients must be couraged to take part in their medical care. Social support must be provided not only for patients but also for their caregivers.

In conclusion, patient adherence to LTOT remains a problem to solve. We need to expend more effort solving compliance and follow-up problems. Written instructions and home care service can be helpful for follow-up and patient education. 


\section{References}

1. Kim V, Benditt JO, Wise RA, Sharafkhaneh A. Oxygen therapy in chronic obstructive pulmonary disease. Proc Am Thorac Soc 2008; 5: 513-8.

2. Mitrouska I, Tzanakis N, Siafakas NM. Oxygen therapy in chronic obstructive pulmonary disease. Eur Respir Mon 2006; 11: 302-12.

3. From the Global Strategy for the Diagnosis, Management and Prevention of COPD, Global Initiative for Chronic Obstructive Lung Disease (GOLD). Available from: http://www.goldcopd.org/ (accessed on August 23, 2012)

4. Dunne PJ. The clinical impact of new long-term oxygen therapy technology. Respir Care 2009; 54: 1100-11.

5. Katsenos S, Constantopoulos SH. Long-Term Oxygen Therapy in COPD: Factors Affecting and Ways of Improving Patient Compliance. Pulm Med 2011: 2011: 325362.

6. Kurtar NP, Uçan ES, Şahbaz S, Ellidokuz H, Çımrın AH, Kurtar E, İtil O, Akkoçlu A. Uzun Süreli Oksijen Tedavisinin Etkinligi ve Hasta Uyumu. Toraks Dergisi 2007; 8: 163-9.

7. Akçay Ş, Eyüboğlu FÖ, Çelik N, Aydın G. Kronik Solunum Yetmezliği Olan Hastalarda Uzun Süreli Oksijen Tedavisi Uyumu ve Etkileyen Faktörler. Tüberküloz ve Toraks Dergisi 2001; 49: 13-20.

8. Yentürk EP, Umut S. Kronik Obstruktif Akciger Hastalığında Uzun Süreli Oksijen Tedavisi Etkinlik ve Uyumu. Solunum 2002; 4: 391-5.

9. Düzenli H, Doğan ÖT, Berk S, Özşahin SL, Akkurt İ. Kronik Solunum Yetmezliği Olan Olgularda Uzun Süreli Oksijen Tedavisinin Yaşam Süresi Üzerine Etkisi. Toraks Dergisi 2008; 56: 179-86.

10. Gulbas G, Gunen H, In E, Kilic T. Long-term follow-up of chronic obstructive pulmonary disease patients on long-term oxygen treatment. Int J Clin Pract 2012; 66: $152-7$.

11. Rizzi M, Grassi M, Pecis M, Andreoli A, Taurino AE, Sergi M, Fanfulla F. A specific home care program improves the survival of patients with chronic obstructive pulmonary disease receiving long term oxygen therapy. Arch of Phys Med Rehabil 2009; 90: 395-401.

12. Demographic Structure of Turkey and its Future, 2010-2050. Available at: http://www.turkstat.gov.tr/PreHaberBultenleri.do?id=13140 (accessed on August 23, 2012) 